\title{
Internalizing Entrepreneurship Values Since the Early Age to Face the 4.0 Industrial Revolution at TK Khalifah Yogyakarta
}

\author{
Ria Astuti ${ }^{1, *}$ Muammar Qadafi ${ }^{2}$
}

\author{
${ }^{1}$ Islamic Early Childhood Education Study Program, Institut Agama Islam Negeri Madura, Pamekasan, Indonesia \\ ${ }^{2}$ Islamic Early Childhood Education Study Program, Universitas Islam Negeri Mataram, Lombok, Indonesia \\ *Corresponding author. Email: ria.astuti@iainmadura.ac.id
}

\begin{abstract}
Indonesia is now facing the 4.0 industrial revolution in which almost all life aspects have used digital technology. A research by McKinsey on the last 2016 revealed that the impact of 4.0 industrial revolution in the next five years will be evident in the shift, or even loss, of 52.6 million types of occupation. In this context, everyone needs to prepare good characters, mentality and skills to actively engage in the competition. If this problem is not responded properly, it will increase the unemployment rate in Indonesia. One of the solutions to this problem is by instilling the value of entrepreneurship to early years' children. This is a qualitative research using descriptive approach and took place in Yogyakarta. The subjects are determined using purposive sampling technique, consisting of parents from various backgrounds of education and occupation as well as teachers in early childhood education institution. This research found that it is very important to internalize entrepreneurship value to early children in facing the 4.0 industrial revolution. The value consists of leadership, honesty, generosity, discipline, responsibility, independency, bravery, skill, creativy and innovation. Meanwhile, the methods of internalization are habituation, exemplary, storytelling, playing games, watching movies as well as questions and answers.
\end{abstract}

Keywords: Entrepreneurship value, early years' children, 4.0 industrial revolution

\section{INTRODUCTION}

Indonesia is currently facing a new industrial era called the era of the industrial revolution 4.0. This term originates from the idea of Arnold Toynbee (Ali \& Ibrahim, 2018). The idea of the fourth industrial revolution was officially born in Germany at the Hannover Fair held in 2011. Most experts argue that the benefits of Industry 4.0 are about improving the speed of production flexibility, increasing service to customers and increasing revenue. The aim of this industrial revolution is to increase the industrial competitiveness of each country to face a very dynamic global market. This condition is caused by the rapid development of digital technology in various fields (Prasetyo \& Sutopo, 2018). Technological advancements make it possible for automation in almost all fields. New technologies and approaches combining the physical, digital and biological world will fundamentally change people's life and interactions (Ghufron, 2018).

Dynamic changes that originally centralized on humans as subjects in the growth and development of the economic pulse have shifted slowly and been replaced by mechanical automation and digitalization. A research by McKinsey in 2016 shows that the impact of industrial revolution 4.0 in the next five years will be evident in the disappearance of 52.6 million jobs. The study tells us that every person who wants to survive in the global competition must mentally prepared, and have skills that different from others' (Suwardana, 2018). Without having unique skills, there will be more unemployment in Indonesia.

It is indicated that education in Indonesia pays little attention to students' character development and entrepreneurial behaviors. It appears that education is only aimed at preparing the workforce. In this context, instilling entrepreneurship values since the early age can be one of the solutions to produce human resources that have character and entrepreneurial spirit in facing the industrial revolution 4.0. Education in Indonesia should pay attention to students' character and entrepreneurial behaviors. Entrepreneurship is in fact a basic education for sustainable development in Nigeria and entrepreneurial learning could equip children with entrepreneurial skills needed in their daily life (Ifunanya, Ohamobi, \& Stella, Ezeaku, 2014). Jones and Jayawarna (2011) added that human resources with an entrepreneurial spirit are longterm outcomes arising from the process of achieving and cognitive abilities during childhood. They also mentioned that most young entrepreneurs who are at the age of 33 years are the result of instilling entrepreneurship values since the early age (Jayawarna, Jones, \& Macpherson, 2014). The findings of Jones and Jayawarna are in line with Sudaryanti who claimed that character education should be applied since the early age because it is crucial to determine a child's ability to develop his/her potential. Character education in early childhood can lead children to 
be more mature in processing emotions. Emotional intelligence is an important provision in preparing early childhood education to face the future that is full of challenges, academically and socially (Sudaryanti, 2012). Instilling entrepreneurship values since the early age is very important because early childhood is the golden period, where children develop rapidly. When given appropriate stimuli, children will have optimal development, which will be until they become adults. This includes familiarizing children with entrepreneurial behaviors. In the age around 0 to 6 years old, children experience a golden period that makes them become sensitive in receiving various types of stimuli. The sensitive period is the time when a physical and psychological function of maturity occurs. In addition, the sensitive period of each child is different from each other. This period is also the first foundation for developing cognitive abilities, socio-emotional, motoric-movement, and language. Early childhood is a developmental period that determines the future of the nation (Hasanah, 2019).

Instilling entrepreneurship values in kindergarten is integrated with existing themes and activities in the institutions. The findings of Farkhati show that entrepreneurship values can be integrated through various development fields, namely: moral and diversity values, social, emotional, and independence, language, cognitive, physical/ motor, and art using various learning methods, cooperative learning strategies, and also through daily activities in kindergarten (Farkhati, 2011). Epistemologically, learning in early childhood should use the concept of learning by playing, learning by doing, and learning by stimulating (Sujiono, 2009).

Parents' understanding of internalizing entrepreneurship values since the early age in Yogyakarta is very high. Based on the observations, one of the entrepreneurialbased ECE institutions in the city is Khalifah Kindergarten whose mission is to ensure that children can aspire to become Muslim entrepreneurs with the example of the Prophet Muhammad Shallallahu 'alaihi wassalam. For these reasons, this kindergarten deserves researching. This study focuses on internalizing entrepreneurship values in since the early age to face the Industrial Revolution 4.0 at the Khalifah Kindergarten in Yogyakarta. The purpose of this study is to describe (1) entrepreneurship values that can be instilled since the early age in TK Khalifah Yogyakarta, (2) the methods used for instilling entrepreneurship values in Khalifah Kindergarten, Yogyakarta.

\section{METHOD}

This research was conducted in TK Khalifah Gedong Kuning Yogyakarta. This is a qualitative research. According to Moleong (2006), a qualitative research intends to understand phenomena experienced by research subjects such as behaviors, perceptions, motivation, etc. holistically and through descriptions by words and language in a particular natural context and by utilizing various natural methods. This is a descriptive research because it is intended to describe a situation or phenomenon as it is (Sukmadinata, 2009). In this study, the researchers aim to describe: (1) entrepreneurship values that can be instilled since the early age in TK Khalifah Yogyakarta; (2) the methods used for instilling entrepreneurship values in TK Khalifah Yogyakarta.

The research subjects were people working at TK Khalifah Yogyakarta, and available documents given access to be observed. The researchers used purposive sampling technique in determining the research participants. Purposive sampling, according to Sugiyono (2008), is a technique for sampling data sources with certain considerations, for example the person who is considered to know the most about what we expect, so that it will facilitate researchers in exploring the object or social situation of the object. The technique in determining the research subject was carried out in order to get the right participants and be able to answer the research questions. The subjects in this study were the principal and teachers of Khalifah Yogyakarta.

The data collection techniques used in this research were:

\subsection{Observation}

This was a participant observation with a moderate participation because researchers involved in activities but there was a balance between fully participation and no participation at all. Researchers only help and assist teachers in carrying out activities, then researchers just observed, noted, and recorded various events that occurred during the activity process. Observations made by researchers described in the form of field notes because it help researchers to record in writing an event in the study.

\subsection{Interview}

Researcher used a semi-structured interview technique by conducting in-depth interviews. The reason is that the researcher could interview the resource person in a situation that is more enjoyable, so that the resource person can more easily express ideas and can explain deeply and honestly. Interviews were conducted using an interview guide, in which the researcher brought guidelines in the form of an outline about the questions that were asked.

\subsection{Documentation}

Documentation was carried out to capture information directly from the research sites available in the form of documents. The information were activity reports, photographs, recorded activities and relevant data. 


\subsection{Data Analysis}

In analyzing data, researchers used the Miles and Huberman models. Activities in data analysis included data reduction, data display, and conclusion drawing/ verification (Sugiyono, 2008).

\section{DISCUSSION}

The term entrepreneurship was first introduced in the early 18th century by the French economist, Richard Cantillon. According to him, entrepreneurs are agent who buys means of production at certain prices in order to combine them. The etymological meaning of entrepreneur comes from Sanskrit, consisting of three syllables: "wira", "swa", and "sta". Wira means superior human, exemplary, tough, virtuous, big-hearted, brave, hero, pioneer, warrior of progress, having the majesty of character. Swa means itself, and Sta means standing. The term entrepreneurship, basically comes from the translation of entrepreneur, which in English is known as between taker or go between. In the Middle Ages the term entrepreneur was used to describe a person who leads a production project. The concept of entrepreneurship was completely put forward by Josep Schumpeter, namely as a person who breaks down the existing economic system by introducing new goods and services, by creating new forms of organization or processing new raw materials. The person carries out his activities through a new or existing business organization. In this definition it is emphasized that entrepreneurship is a person who sees an opportunity then creates an organization to take advantage of the opportunity (Hasanah, 2019).

There are many different definitions about Industry 4.0. German Chancellor Angela Merkel believes that Industry 4.0 is a comprehensive transformation of all aspects of production in the industry through the merger of digital and internet technologies with conventional industries. Schlechtendahl emphasizes the definition of the speed element of the availability of information, which is an industrial environment in which all entities are always connected and able to share information with each other. A more technical understanding was conveyed by Kagermann that Industry 4.0 is the integration of the Cyber Physical System (CPS) and the Internet of Things and Services (IoT and IoS) into industrial processes including manufacturing and logistics and other processes. CPS is a technology to combine the real world with the virtual world. This integration can be realized through integration between physical processes and close loop computation (Prasetyo \& Sutopo, 2018).

Industrial Era 4.0 is used to refer to an era where there is a combination of technology that results in physical, biological, and digital dimensions forming a combination that is difficult to distinguish. For example, two people can share information directly with digital assistance without having to be in the same place or at the same time both physically and biologically (Putrawangsa \& Hasanah,
2018). Based on some of the explanations above, Industry 4.0 can be interpreted as an industrial era in which all entities in it can communicate with each other in real time at any time.

The internalization of entrepreneurial values in early childhood in facing the industrial revolution 4.0 is very important. This is a step where children are able to face changes that occur on the basis of digitalization. If children are not prepared mentally early, it will become a boomerang for their lives in the future because they are unable to compete with others. Children who are instilled with entrepreneurial values early on are expected to have the character of leadership, honesty, generous, disciplined, responsible, independent, brave, confident, skilled, creative, and innovative. If the child will become a good businessman, then his life must be forged to have a positive character. This is summarized in the author's scheme as follows:

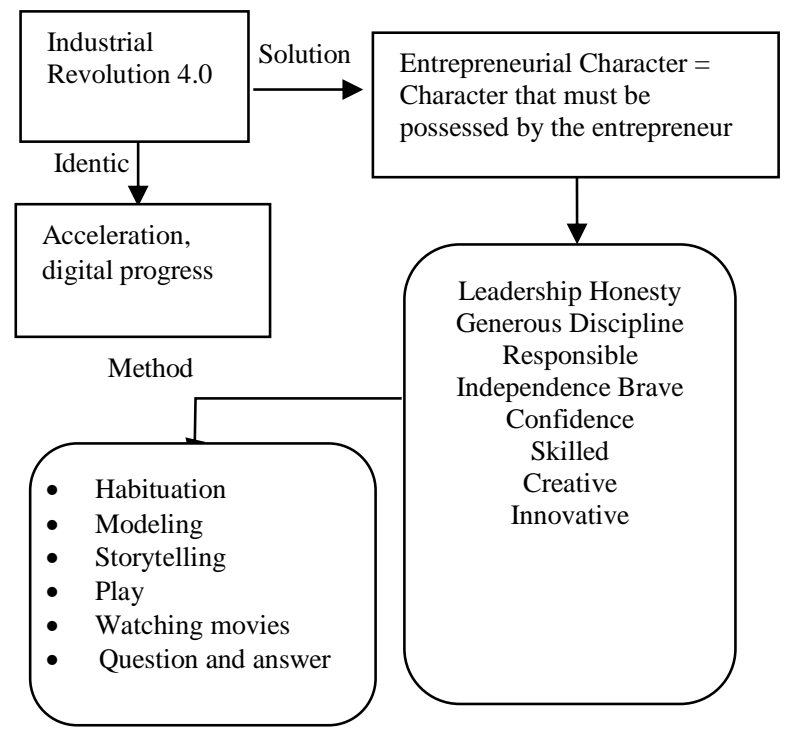

Figure 1 Entrepreneurship character investment scheme in early childhood

Some of the characters that have been mentioned above, are the effects of the cultivation of entrepreneurship in early childhood at the Khalifah Kindergarten Yogyakarta through various learning activities in this school with various learning methods. Based on the interviews with the Principal of the Khalifah Kindergarten, it can be seen that there are several learning programs that can instill entrepreneurial value in early childhood at this institution, namely: market day, field trip, and cooking day which are delivered as follows:

Children are scheduled to look after a small supermarket on market day at school. Market day or school market is an activity that is routinely carried out to instill an entrepreneurial spirit early on. From the capital provided by educators, students make a product that can be sold. The income from the sale will be donated and the donation can be money or rice package and distributed to the poor in the surrounding environment. 
Children are invited to sell something around the school. This activity also provides tangible experiences for students to practice directly selling in the environment around the school. This activity trains a lot of entrepreneurial values in students, especially the values of courage, tenacity, cooperation, and hard work.

Children are invited to do sharing activities on Friday. The profit of the sale is distributed to the people who needed. This activity trains children to be a generous person.

Children learn to make crafts that can be used as works and can be sold to practice being entrepreneurs. This can foster the character of independence, responsibility, courage, self-confidence, skillfulness, as well as creative and innovative.

Children are routinely invited to Outing activities in various business places such as: banks, supermarkets, practice of making cakes and noodles, animal husbandry, market events and alms on car free day. This activity can grow the character of leadership, skilled, creative and innovative in early childhood.

Some of the activities above are concrete steps of the Khalifah Kindergarten in Yogyakarta to achieve their goals, namely to make their students grow into entrepreneurs. With these various activities, entrepreneurial values have begun to be embedded in students from an early age. The development of learning activities based on life skills is one of the provisions for students to face their future, especially in facing 4.0 industrial revolution.

Some methods in instilling entrepreneurial character in early childhood in Yogyakarta Khalifah Kindergarten as informed by the principle, namely: habituation, exemplary, telling stories, playing, watching films, and question and answer.

Habituation is accustoming students to implement learning programs that have been determined by the institution.

Exemplary. Before applying to students on the various habits that have been mentioned above, the educator must be a precedent in their students. For example: Educators also take daily Dhuha prayers, not only their children.

Storytelling can be done with hand puppets or other learning media. But it can also be without learning media, because it is adjusted to the creativity of the educator. Educators also explain the meaning of each habituation that students do, so that students not only carry out an accustomed activity, but understand the benefits of the activity.

Playing can be done by playing roles or playing using other learning media. In addition, students are invited to count without imposing their development which is done by playing methods.

Watching movies. The film here is a film that is rich in entrepreneurial character education values on youtube or television.

Question and answer. It is to make children understand about what activities or activities they have done and what the benefits are.

Based on the observations and interviews by the author, it can be seen that some of the methods above can instill entrepreneurial character in early childhood at TK
Khalifah Yogyakarta to face the industrial revolution 4.0 appropriately.

\section{CONCLUSION}

The internalization of entrepreneurship values since the early age is very important as an effort to face the industrial revolution 4.0. Some of the entrepreneurship values that can be taught since the early age are leadership, honesty, generosity, discipline, responsibility, independence, bravery, confidence, creativity and innovation. Some methods to instill entrepreneurship values since the early age are namely: habituation, exemplary, story-telling, playing, watching movies, and questions and answers.

\section{REFERENCES}

Ali, R. N. A. B. R., \& Ibrahim, M. B. (2018).

Preparation of politechnic Sultan Mizan Zainal Abidin (PSMZA) lecturers in facing the industrial revolution flow 4.0. Jurnal Konseling dan Pendidikan, 6(3), 181190.

Farkhati, E. (2011). Integrasi nilai-nilai kewirausahaan dalam praktik pembelajaran di taman kanak-kanak muslimat Nurul Huda Desa Pakujati Kecamatan Paguyangan Kabupaten Brebes (Bachelor Thesis, Universitas Negeri Semarang). Retrieved from https://lib.unnes.ac.id/11689/1/9103.pdf

Ghufron, G. (2018, September). Revolusi Industri 4.0: Tantangan, Peluang, dan Solusi bagi Dunia Pendidikan. In Seminar Nasional dan Diskusi Panel Multidisiplin Hasil Penelitian dan Pengabdian Kepada Masyarakat, 1(1), 332-337.

Hasanah, U. (2019). Upaya Menumbuhkan Jiwa Entrepreneurship melalui Kegiatan Market Day bagi Anak Usia Dini. DEDIKASI: Jurnal Pengabdian Masyarakat, 1(1), 9-19.

Ifunanya, N., Ohamobi, N., \& Stella, N., Ezeaku. (2014) Entrepreneurship in Universal Basic Education For Sustainable Development In Nigeria. ANSU Journal of Developmental Studies (3)1, 40-49.

Jayawarna, D., Jones, O., \& Macpherson, A. (2014). Entrepreneurial Potential: The Role of human capital. Institute for Small Bussiness and entrepreneuship: United Kingdom, 32(8), 2011. doi:10.1177/0266242614525795

Jones, O., \& Jayawarna, D. (2011). Entrepreneurial potential: the role of human capital. United Kingdom: Institute for small bussiness and entrepreneuship. 
Moleong, L. J. (2006). Metode penelitian kualitatif edisi revisi. Bandung: Remaja Rosdakarya.

Prasetyo, H., \& Sutopo, W. (2018). Industri 4.0: Telaah Klasifikasi aspek dan arah perkembangan riset. J@ti

Undip: Jurnal Teknik Industri, 13(1), 17-26.

Putrawangsa, S., \& Hasanah, U. (2018). Integrasi teknologi digital dalam pembelajaran di era industri 4.0. Jurnal Tatsqif, 16(1), 42-54.

Sudaryanti, S. (2012). Pentingnya pendidikan karakter bagi anak usia dini. Jurnal Pendidikan Anak, 1(1), 1120. doi: https://doi.org/10.21831/jpa.v1i1.2902

Sugiyono. (2008). Metode penelitian pendidikan:

Pendekatan kuantitatif, kualitatif dan R\&D. Bandung: Alfabeta.

Sujiono, Y. N. (2009). Konsep dasar pendidikan anak usia dini. Jakarta: Indeks.

Sukmadinata, N. S. (2009). Metode penelitian pendidikan. Bandung: PT. Remaja Rosdakarya.

Suwardana, H. (2018). Revolusi Industri 4. 0 Berbasis Revolusi Mental. JATI UNIK: Jurnal Ilmiah Teknik dan Manajemen Industri, 1(2), 102-110. 